\title{
Inflammatory Rectal Polyp with Osseous Metaplasia: Is It a Distinctive Disease Entity?
}

\author{
Kemik Metaplazisinin Eşlik Ettiği İnflamatuar Rektal Polip: Ayrı Bir Antite mi?
}

\author{
Cansu BENLİ IŞIK ${ }^{1}$ \\ (D) 0000-0003-3805-3143 \\ Hatice ÖLGER UZUNER ${ }^{1}$ \\ (D) 0000-0002-9769-5122 \\ Mustafa BAKIRTAŞ ${ }^{1}$ \\ (D) 0000-0003-3185-6947 \\ Ahmet SARAC 2 \\ (D) 0000-0001-9308-1417
}

\begin{abstract}
Osseous metaplasia is a heterotopic bone formation and it is encountered rarely in the gastrointestinal tract, especially in benign lesions. Although its pathophysiology is not known clearly, there are several theories suggested. In this case report, we presented a case of bone formation in a rectal inflammatory polyp presenting with rectal bleeding in a 7-year-old girl. Therewithal, we reviewed the literature and summarized the subject of osseous metaplasia in colon polyps. We detected some similarities in the cases presented that suggest it might be a distinctive disease entity. Osseous metaplasia in colorectal polyps is extremely rare. To our knowledge, this is the eleventh reported case of osseous metaplasia in a rectal inflammatory polyp. Although osseous metaplasia in colon polyps has not a significant effect on both clinic and the prognosis, it can be confusing when encountered in microscopic examination.

Keywords: Osseous metaplasia; heterotopic ossification; rectal polyp; colonic polyps; ectopic ossification.
\end{abstract}

\section{öz}

Osseoz metaplazi, heterotopik kemik oluşumudur ve gastrointestinal sistemde, özellikle benign lezyonlarda nadiren karşılaşılır. Patofizyolojisi net olarak bilinmemekle birlikte bazı teoriler öne sürülmüştür. Bu olgu sunumunda, 7 yaşında bir kız çocuğunda rektal kanama ile bulgu veren kemik metaplazili inflamatuar rektal polip olgusunu sunduk. Aynı zamanda literatürü taradık ve kolon poliplerinde osseoz metaplazi olgularını özetledik. Sunulan vakalarda bunun spesifik bir antite olabileceğini düşündürten, bazı benzerlikler saptadık. Kolorektal poliplerde osseoz metaplazi oldukça nadirdir. Saptadığımız kadarıyla olgumuz osseoz metaplazi içeren on birinci rektal inflamatuar polip vakasıdır. Kolon poliplerinde osseoz metaplazi hem klinik hem de prognoz üzerinde önemli bir etkiye sahip olmasa da, mikroskopik incelemede karşılaşıldığında kafa karıştırıcı olabilir.

Anahtar kelimeler: Osseoz metaplazi; heterotopik ossifikasyon; rektal polip; kolon polipleri; ektopik kemikleşme.

\section{INTRODUCTION}

Osseous metaplasia (heterotopic bone formation) is rarely encountered in the gastrointestinal tract (1). Most of the reported cases are associated with malignant lesions and are extremely rare in benign colonic polyps (2-4). Very few cases have been reported, especially in the pediatric population. Although its pathophysiology is not known clearly, there are several theories suggested (5).

In this case report, we presented a case of bone formation in a rectal inflammatory

Received / Geliş Tarihi : 13.03.2021 Accepted / Kabul Tarihi : 21.07.2021 Available Online /

Çevrimiçi Yayın Tarihi : 04.08.2021 polyp presenting with rectal bleeding in a 7 -year-old girl. 


\section{CASE REPORT}

A seven-year-old girl applied to the clinic with the complaint of rectal bleeding following defecation for the last week. There was no previous history of constipation or rectal bleeding. On physical examination, a petiolate polypoid lesion with a diameter of approximately $1.5 \mathrm{~cm}$ was observed in the knee-elbow position, $3 \mathrm{~cm}$ above the dentate line and at 1 o'clock in the rectum. There was no history of rectal bleeding in the family. In addition, no pathology was detected in the laboratory findings, hemoglobin level was $12.9 \mathrm{~g} / \mathrm{dl}$. The polyp was excised under general anesthesia. No other polypoid lesions were detected from up to the first $10 \mathrm{~cm}$ of the rectum.

On macroscopic examination, a pink-skin colored polypoid tissue measured $1.7 \times 1.5 \times 0.5 \mathrm{~cm}$ was observed. In the microscopic examination; the polyp surface was ulcerated and covered with fibrinopurulent debris. Acutechronic inflammation was observed with the development of granulation tissue in the stroma (Figure 1). Elongated, dilated, mucin-filled and some ruptured colonic glands were observed in this enflamed stroma. Some of the ruptured glands showed mucin scattered into the stroma (Figure 2). Multiple foci of bone formation surrounded by osteoblasts were observed in the stroma, whereas no bonemarrow tissue was observed (Figure 3).

Consent was obtained from the patient.

\section{DISCUSSION}

Heterotopic bone formation is not a common finding in colon polyps. To the best of our knowledge, 28 cases have been presented in the English literature so far (6-22). Eight of them were dysplastic, whereas others were inflammatory and juvenile polyps. The cases of colon polyps including osseous metaplasia that we detected as a result of the literature review are summarized in Table 1. When the cases are classified as dysplastic and nondysplastic; the male:female ratio in the non-dysplastic (juvenile and inflammatory polyps) group is calculated as 4:1. The majority of cases are young patients. While one patient in this group is 74 years old, the age range of the other patients is 3-39 (mean age 17.2). The lesion was in the anal canal in 1 case, in the rectosigmoid are in 2 cases and in the rectum in other cases. Polyp sizes vary between $5-95 \mathrm{~mm}$. Although the size of one of these 20 nondysplastic polyps is unknown, $16(80 \%)$ are $2 \mathrm{~cm}$ or less.

The pathogenesis of osseous metaplasia is not fully known, and different mechanisms have been suggested. In 1964, Marks and Atkinson (13) suggested that osseous metaplasia may develop as a result of transformation of fibroblasts into mesodermal tissue types such as osteoblasts and chondroblasts.

A case of rectal adenocarcinoma with heterotopic ossification was reported in the literature review of study by Ansari et al. (23) in which 52 cases of osseous metaplasia in the gastrointestinal system was included. Adenocarcinoma was diagnosed in 47 of 52 cases, and osseous metaplasia was mostly seen with primary tumors. Furthermore, mucin production has been observed widely in these tumors. They reported that necrosis, inflammation, calcification, increased vascularization and extracellular mucin accumulation were associated with heterotopic bone formation in tumors. Mucin was also present in the stroma of our case.

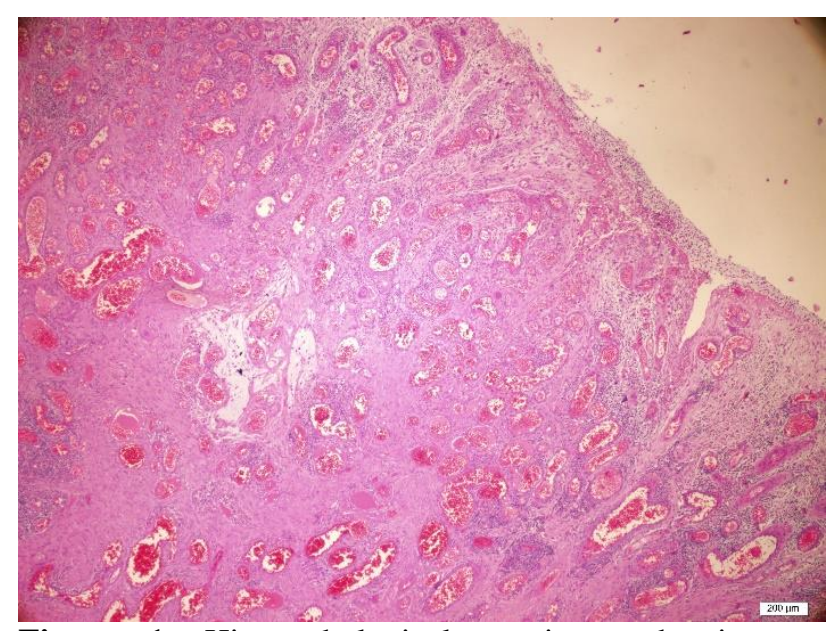

Figure 1. Histopathological specimen showing an ulcerated polyp with underlying inflammation and granulation tissue formation $(\mathrm{H} \& \mathrm{E}, \mathrm{x} 40)$

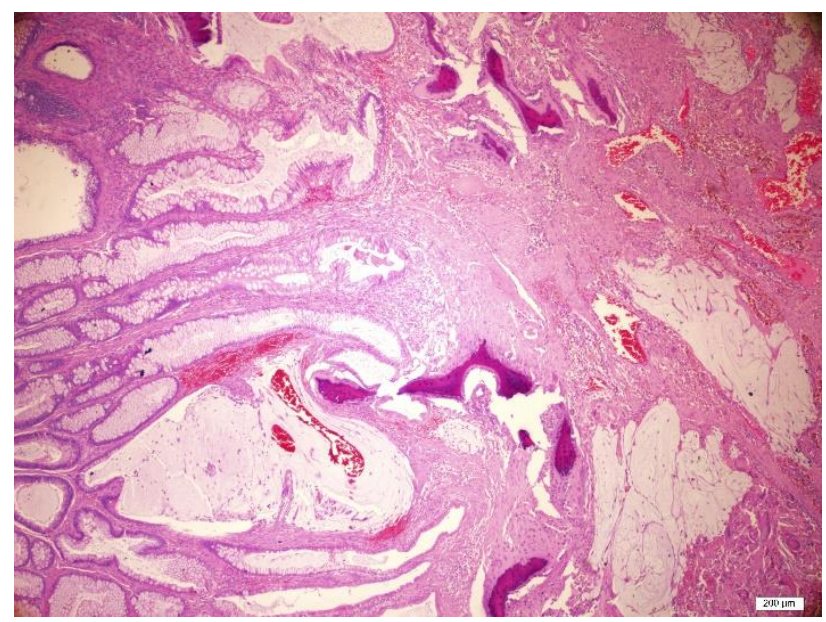

Figure 2. Histopathological specimen showing elongated, dilated, some ruptured colonic glands and areas of osseous metaplasia within an inflamed stroma (H\&E, x40)

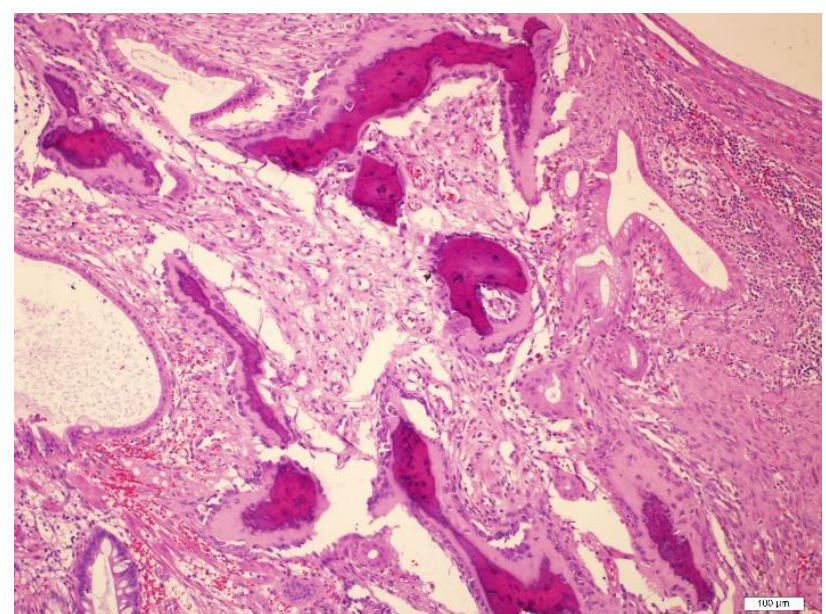

Figure 3. Histopathological specimen showing bone formation that some of them surrounded by osteoblasts (H\&E, x100) 
Table 1. Summary of our and previously reported cases of osseous metaplasia in colorectal polyps

\begin{tabular}{|c|c|c|c|c|c|c|}
\hline No & Year & Author & Age & Gender & Site & Size (mm) \\
\hline \multicolumn{7}{|c|}{ Dysplastic ( 3 of tubulovillous adenoma, 3 of tubular adenoma, 2 of traditional serrated adenoma) } \\
\hline 1 & 1994 & Groisman (6) & 67 & Male & Rectum & 18 \\
\hline 2 & 1996 & Cavazza (6) & Unknown & Unknown & Unknown & Unknown \\
\hline 3 & 1999 & McPherson (7) & 73 & Male & Cecum & 20 \\
\hline 4 & 2000 & Rothstein (8) & Unknown & Unknown & Sigmoid colon & 25 \\
\hline 5 & 2005 & Al-Daraji (9) & 85 & Female & Sigmoid colon & 15 \\
\hline 6 & 2008 & White (10) & 63 & Female & Transverse colon & Unknown \\
\hline 7 & 2010 & Wilsher (11) & 50 & Male & Rectosigmoid & 25 \\
\hline 8 & 2012 & Montalvo (12) & 62 & Male & Rectum & 50 \\
\hline \multicolumn{7}{|c|}{ Juvenile Polyp } \\
\hline 9 & 1964 & Marks (13) & 10 & Male & Rectum & Unknown \\
\hline 10 & 1992 & Drut (14) & 5 & Male & Rectosigmoid & 10 \\
\hline 11 & 1992 & Drut (14) & 4 & Male & Rectum & 5 \\
\hline 12 & 1994 & Groisman (6) & 3 & Female & Rectum & 20 \\
\hline 13 & 2009 & Ahmed (15) & 17 & Male & Rectum & 18 \\
\hline 14 & 2012 & Bhat (16) & 5 & Female & Rectum & 15 \\
\hline 15 & 2013 & Garg (17) & 6 & Male & Rectum & 13 \\
\hline 16 & 2016 & Naimi (18) & 10 & Male & Rectum & 30 \\
\hline 17 & 2018 & Haynes (19) & 6 & Male & Rectosigmoid & 15 \\
\hline \multicolumn{7}{|c|}{ Inflammatory polyp } \\
\hline 18 & 1981 & Sperling (20) & 25 & Male & Rectum & 10 \\
\hline 19 & 1992 & Castelli (6) & 22 & Female & Rectum & 10 \\
\hline 20 & 2009 & Oono (3) & 39 & Male & Rectum & 12 \\
\hline 21 & 2012 & Odum (14) & 74 & Male & Rectum & 10 \\
\hline 22 & 2013 & Bhattacharya (21) & 14 & Male & Rectum & 10 \\
\hline 23 & 2014 & Zemheri (6) & 9 & Male & Rectum & 8 \\
\hline 24 & 2016 & Stevanovic (2) & 31 & Male & Anal canal & 57 \\
\hline 25 & 2019 & $\operatorname{Lim}(22)$ & 30 & Male & Rectum & 18 \\
\hline 26 & 2019 & Amir (4) & 10 & Male & Rectum & 95 \\
\hline 27 & 2020 & Wood (5) & 17 & Male & Rectum & 12 \\
\hline 28 & 2020 & Our case & 7 & Female & Rectum & 17 \\
\hline
\end{tabular}

In some recent studies, it has been reported that the expression of bone morphogenetic proteins (BMPs) plays a role in the pathogenesis of bone metaplasia. In their study published in 2001; Imai et al. (24) showed that BMP-2, BMP-4, BMP-5 and BMP-6 are expressed in colonic adenocarcinomas with osseous metaplasia. In their study published in 2003; Kawai et al. (25) transferred the human BMP-2 gene to the skeletal muscle of rats by cutaneous electroporation and observed the formation of ectopic bone consisting of active osteoblasts and osteoclasts in all rats.

Wood et al. (5) presented a case of inflammatory rectal polyp with osseous metaplasia in a 17-year-old patient in their recent article and suggested that this may be a distinctive disease entity. We share the same perspective with them. Considering the presented cases of colon polyps with osseous metaplasia, the fact that most of the non-dysplastic patients are young male patients and almost all of them are located in the rectum suggest that this may be a specific entity and that recurrent traumas caused by defecation may also play role in the pathogenesis.
In conclusion, we present a rare case of osseous metaplasia in inflammatory rectal polyp. Although osseous metaplasia in colon polyps has not a significant effect on both clinic and the prognosis, it can be confusing when encountered in microscopic examination. It will be better to know that seeing osseous metaplasia will not change our original definition.

Informed Consent: Written informed consent was obtained from the patient for publication and accompanying images.

Conflict of Interest: None declared by the authors.

Financial Disclosure: None declared by the authors.

Acknowledgements: None declared by the authors.

Author Contributions: Idea/Concept: CBI; Design: CBI;

Data Collection/Processing: CBI, MB, AS; Analysis/Interpretation: CBI, MB; Literature Review: CBI; Drafting/Writing: CBI; Critical Review: CBI, HÖU. 


\section{REFERENCES}

1. Singh P, Nayyar A, Karandikar MN. Osseous metaplasia in hyperplastic gastric polyp -A rare case report with review of literature. Hum Pathol Case Rep. 2020;22:200439.

2. Stevanović D, Aleksić V, Stojanović D, Mitrović N, Jašarović D, Bokun-Vukašinović Z. Osseous metaplasia in an inflammatory polyp of the anal canal - a case report and a review of literature. Srp Arh Celok Lek. 2019;147(3-4):211-4.

3. Oono $\mathrm{Y}, \mathrm{Fu} \mathrm{KL}$, Nakamura $\mathrm{H}$, Iriguchi $\mathrm{Y}$, Oda J, Mizutani M, et al. Bone formation in a rectal inflammatory polyp. World J Gastrointest Endosc. 2010;2(3):104-6.

4. Amir AA, Nouli KA, Sheikh SS. Benign prolapsing inflammatory rectal polyp with osseous metaplasia mimicking rhabdomyosarcoma botryioides. J Ped Surg Case Rep. 2020;56:101297.

5. Wood R, Wu T, Nakanishi Y. Osseous metaplasia in a rectal inflammatory polyp in an adolescent patient: A case report and review of the literature. Front Med Case Rep. 2020;1(2):1-5.

6. Zemheri E, Toprak M, Engin Zerk P, Ozkanli S, Mutus M. Inflammatory rectal polyp with osseous metaplasia. Med Med J. 2015;30(3):143-6.

7. McPherson F, Maldonado M, Truitt CA, Mamel JJ, Morgan MB. Metaplastic ossification of a benign colonic polyp: case report. Gastrointest Endosc. 1999;49(5):654-6.

8. Rothstein RD, LiVolsi VA. Metaplastic ossification of a benign colonic polyp. Gastrointest Endosc. 2000;51(2):254.

9. Al-Daraji WI, Abdellaoui A, Salman WD. Osseous metaplasia in a tubular adenoma of the colon. J Clin Pathol. 2005;58(2):220-1.

10. White V, Shaw AG, Tierney GM, Lund JN, Semeraro D. Osseous metaplasia in an ulcerating tubular adenoma of the colon: a case report. J Med Case Rep. 2008;2:130.

11. Wilsher MJ, Mendelsohn GB. Osseous metaplasia in a traditional serrated adenoma of the rectosigmoid colon. Pathology. 2010;42(3):302-4.

12. Montalvo NF, Beltrán JN, Redrobán LA. Traditional serrated adenoma of the sigmoid colon with osseous metaplasia: a case report. J Med Case Rep. 2012;6:133.
13. Marks MM, Atkinson KG. Heterotopic bone in a juvenile rectal polyp: Case Report. Dis Colon Rectum. 1964;7(5):345-7.

14. Odum BR, Bechtold ML, Diaz-Arias A. Osseous metaplasia in an inflammatory polyp of the rectum: A case report and review of the literature. Gastroenterology Res. 2012;5(2):74-8.

15. Ahmed R, Ahmad Z, Qureshi A. Osseous metaplasia in a juvenile retention polyp: a case report. BMJ Case Rep. 2009;2009:bcr03.2009.1650.

16. Bhat V, Roopa ANN, Shariff S. Juvenile rectal polyp with osseous metaplasia - A rare case with review of literature. Int J Health Sci Res. 2012;2(8):114-6.

17. Garg M, Kaur J, Bindroo S, Sharma A, Mahajan NC. Metaplastic ossification in a juvenile rectal polyp: A rare histological finding. J Clin Diagn Res. 2013;7(5):908-10.

18. Naimi A, Hosseinpour M. Osseous metaplasia in rectal polyp: A case report with review of probable pathogenesis. Adv Biomed Res. 2018;7:78.

19. Haynes HR, Wiskin AE, Basude D, Gradhand E. Osseous metaplasia in a juvenile rectal polyp. J Pediatr Gastroenterol Nutr. 2018;67(6):e123.

20. Sperling MH, Friedman CJ. Osseous metaplasia in a benign colon polyp. Gastrointest Endosc. 1981;27(3):198-9.

21. Bhattacharya N, Sarkar T. Osseous metaplasia in a juvenile polyp: A rare case report in India. J Clin Diagn Res. 2013;7(9):2004-5.

22. Lim D, Schulberg S, Suarez Y, Gadangi P. Osseous metaplasia in a recurrent symptomatic rectal lesion: a rare occurrence. Int J Colorectal Dis. 2019;34(10):1801-3.

23. Ansari MQ, Sachs IL, Max E, Alpert LC. Heterotopic bone formation in rectal carcinoma. Case report and literature review. Dig Dis Sci. 1992;37(10):1624-9.

24. Imai N, Iwai A, Hatakeyama S, Matsuzaki K, Kitagawa Y, Kato S, et al. Expression of bone morphogenetic proteins in colon carcinoma with heterotopic ossification. Pathol Int. 2001;51(8):643-8.

25. Kawai M, Bessho K, Kaihara S, Sonobe J, Oda K, Iizuka $\mathrm{T}$, et al. Ectopic bone formation by human bone morphogenetic protein-2 gene transfer to skeletal muscle using transcutaneous electroporation. Hum Gene Ther. 2003;14(16):1547-56. 